\title{
Suitability of Soil for Earth Construction as Building Material
}

\author{
Humphrey Danso* \\ Department of Construction and Wood Technology, University of Education Winneba, Ghana
}

*Corresponding author: Humphrey Danso, Department of Construction and Wood Technology, University of Education Winneba, Kumasi, Ghana, Email: hdanso@uew.edu.gh/dansohumphrey@yahoo.co.uk

Submission: 海 September 27, 2018; Published: 海 October 22, 2018

\begin{abstract}
In order to check the suitability of soil to be used as construction material for earth construction, its geotechnical properties are required to be assessed. The purpose of this study is to review previously published studies soil samples and compare them with soil suitability criteria and for selecting suitable soil for earth construction. The geotechnical properties of soil samples used in previous studies were compiled and compared with various requirements to ascertain their suitability for construction purposes. Eighty-nine (89) studies in all were consulted and useful data were found in fifty-two (52) of them. Five geotechnical properties of soil were compiled and analysed. These properties are particle size distribution, Atterberg limits, specific gravity, maximum dry density and optimum moisture content. Based on the values of soil properties found in literature, recommendations were made for the suitability of different soil samples for three main techniques (adobe, rammed earth and compressed earth blocks) application in earth construction, while other soil samples were found to be outside the recommendations. It was found that some of the earth construction techniques which were adopted in the previous studies are different from the recommended techniques. It was also observed that some of the soil samples found to be suitable for a particular property test were unsuitable for the other property tests. The study concludes that determining the suitability of the soil for earth construction is important and any soil that is found unsuitable should be enhanced with stabilisers before use.
\end{abstract}

Keywords: Adobe blocks; Compressed earth blocks; Earth construction; Geotechnical properties; Soil suitability; Rammed earth

\section{Introduction}

A soil is a material that is widely available in almost everywhere in the world and can be used in many types of earth construction, such as cob, rammed earth or stabilized mud blocks [1]. Major geotechnical problems in construction involving silty-clayey soils are due to their low strength, durability and high compressibility of soft soils, and the swell-shrink nature of the over-consolidated swelling soils [2]. The poor conditions of soils on their properties can often be a significant impediment to successfully implementing green infrastructure projects [3]. A major problem prior to the decision to use soil as the walling material on a construction project is to identify a sufficient supply of soil suitable for economic stabilization [4]. Earthen construction has been one of the most largely used construction techniques in different historical ages [5]. Earthen materials are still widely used worldwide because of their low-cost, abundance, availability and low environmental impact $[6,7]$. Earth as a building material is increasingly being studied for its low environmental impact and its availability [8]. Utilization of locally available soil for the construction will optimize the cost and reduce the environmental impact [9]. The will of reducing environmental and social impact from the construction industry has led to a renewed interest in earth construction [10]. Due to the ease and simplicity of earth building techniques, a local unskilled labour force can be readily employed, supplying job opportunities to remote communities and reduction in the cost of accommodation and transport of labour brought from distance [11]. Earth building techniques make use of raw earth as a material for constructing walls, and that evaluation of soils is a primary issue because not all soils are adequate in properties for earth buildings [12]. Geotechnical properties of soils influence the stability of civil engineering structures, and most of the geotechnical properties of soils influence each other [13].

Adegun and Adedeji [14] aggregated and reviewed the empirical evidence to show the advantages and disadvantages of earthen construction materials in terms of cost, energy and thermal properties of 136 academic outputs from 17 African countries. Hamard et al. [10] analysed the bibliographical data on cob process and summarized the different cob process variations in an attempt to take into account their diversity. Laborel Préneron et al. [8] reviewed the state of the art of research on the influence of various natural and renewable resources in unfired earth materials such as compressed earth blocks, plasters, and extruded and stabilized blocks based on 50 major studies. Their study included the characterization of the particles and treatments, recapitulative tables of the material compositions, the physical, mechanical, hygrothermal and durability performances of earthbased materials. Danso et al. [15] reviewed 56 published studies on the effect of stabilization on the performance characteristics of soil blocks and found that few studies have been conducted on 
durability properties of enhanced soil blocks as compared with physicomechanical properties. Delgado and Guerrero [12] reviewed more than 20 technical documents including standards from National Standards bodies, analysed the provisions they offered concerning soil suitability for the use of unstabilised earth and analysed the different approaches and kinds of recommendation offered.

Bryan [4] summarized the characteristics and compared the limits that have been suggested from other studies and also conducted laboratory programme on 15 soils from the South West of England to identify the textural and plasticity characteristics of soils with the potential for stabilization with cement. Ciancio and Jaquin [16] studied the limits of the available guidelines and determined whether the recommended assessment criteria are appropriate. Their study concluded that more research is needed to understand the effect of water suction, water-cement ratio and mineralogy of clay in the mechanical behaviour of rammed earth. Maniatidis and Walker [17] reviewed the state of the art of rammed earth construction as published in over 200 books, journal and conference papers, scientific reports and other articles, and in addition presented the historic rammed earth projects in the UK. In the study by Roy and Bhalla [13], different geotechnical properties of soils such as specific gravity, density index, consistency limits, particle size analysis, compaction, consolidation, permeability and shear strength and their interactions and applications for the purpose of civil engineering structures were discussed.

To check the suitability of soil to be used as a foundation or as construction materials, its properties are required to be assessed [18]. The evaluation of basic engineering properties of soils through laboratory testing is very important in understanding and interpreting how soils will behave in the field [19]. The physical and engineering properties of existing soils are intrinsic and can be used as a frame of reference for the behaviour of strength characteristics of soil $[20,21]$. Different kinds of soil exist worldwide with different characteristics which are likely to have effects on the performance of the structures that are constructed with the soil. It is imperative to identify the characteristics of any obtainable soil before using it for construction purposes. Natural soil exists in the distinct composition of sizes, for which certain proportions of these sizes can make a good material for building structures. This presents the need for testing any given soil before it is used in the construction industry as a filling or structural material. The issue is that, given the fact that not all soils are suitable, and some classes are better depending on the technique used, it is necessary to use some way for evaluating them [12]. This study, therefore, reviews and analyse soil properties in literature in order to determine their suitability for earthen construction.

\section{Method}

The study adopted a mixed approach with data from a number of previous studies' results (as secondary data) extracted and analysed. The geotechnical properties of soil samples used in previous studies were compiled and compared with various criteria and requirements to ascertain their suitability for construction purposes. Eighty-nine (89) studies in all were consulted and useful data were found in fifty-two (52) of them. Five geotechnical properties of soil were compiled and analysed. These properties are particle size distribution, Atterberg limits, specific gravity, maximum dry density and optimum moisture content. A wide range of properties exists for determining the characteristics of soil for construction purposes [15]. However, these properties were selected because they are the main properties used in most previous studies to characterise the soil samples.

For particle size distribution and Atterberg limits of soil samples used in previous studies, their values and the techniques used were compiled in tables and then compared with the upper limits of various criteria and requirements. Out of the comparison, a suitable soil application technique of the soil samples based on the requirements were recommended. This helped in determining the suitability of the soil for earth construction. Figure 1 shows the upper limits of Atterberg limit values proposed as a guide to recommend soil samples used in previous studies for determining their suitability for earth construction based on different criteria by Doat et al. [22], Spence and Cook [23] and Delgado and Guerrero [12]. From Figure 1, it can be seen that the study used upper limits of $50 \%$ and $30 \%$, respectively for the liquid limit $\left(W_{\mathrm{L}}\right)$ and plasticity index $\left(P_{\mathrm{I}}\right)$.

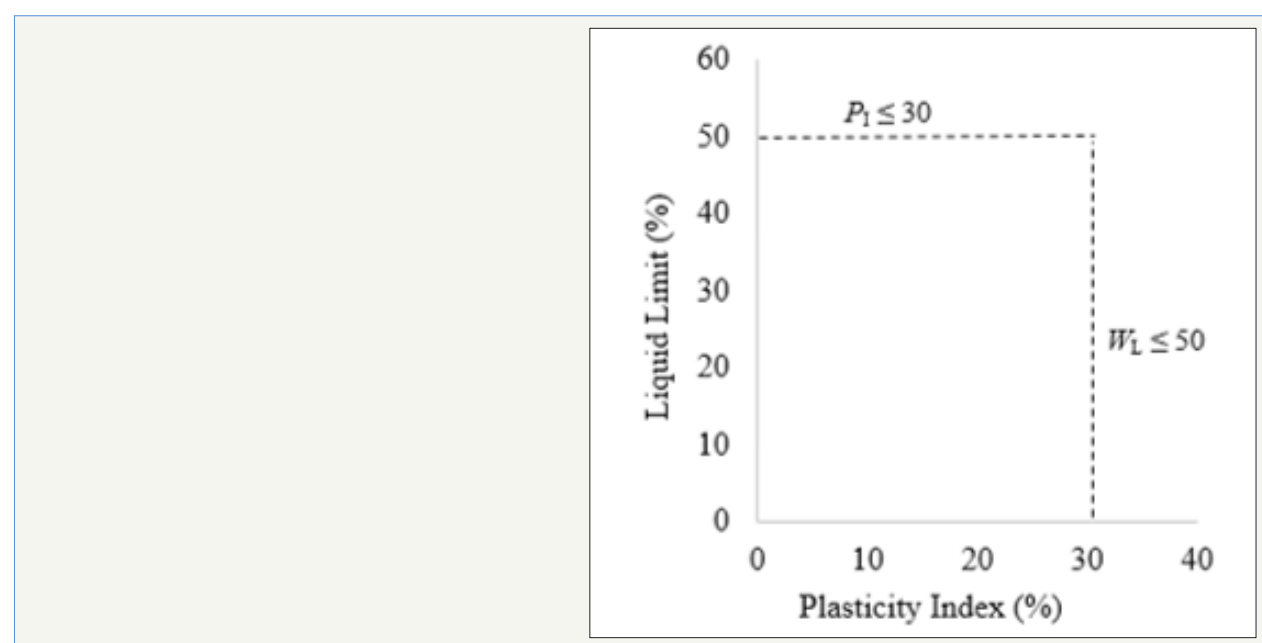

Figure 1: Atterberg limits for soil suitability. 
Similarly, specific gravity, maximum dry density and optimum moisture content of soil samples used in previous studies were also compiled and analysed based on the various requirement and closely related spacing of the values of the soil properties. FM5472 [24] provides a different range of specific gravity values for different types of soil. It, however, provides a specific gravity of 2.00 and 2.80 for the lowest and highest, respectively for all types of soils. Therefore, the study adopted 2.00 and 2.80 as the lower and upper limits, respectively for the suitable specific gravity of soil samples for earth construction. There are no known criteria for acceptable optimum moisture content and maximum dry density for soil suitability for earth construction, therefore, the study considered values that are closely related as suitable optimum moisture content and maximum dry density.

\section{Results and Discussion}

\section{Particle size distribution}

The particle size distribution test determines the amount, usually by mass, of the particles present in a soil sample [25].
Particle size distribution also known as grain size gives information on the soil's ability to pack into a dense structure [26]. The particle sizes are classified as gravel, sand (fine and coarse), silt and clay. There are different recommendations for soil particle sizes that are suitable for different techniques of earth building. Five of these recommendations are put together in a nomogram (see Figure 2) by Delgado and Guerrero [12]. Compressed earth block (CEB) was recommended by Houben and Guillaud [27], CRATerre EAG [28] and AFNOR [29]. While Adobe was recommended by Houben and Guillaud [27] and CRATerre EAG [28], and rammed earth (RE) recommended by Houben and Guillaud [27]. Another source [23] made a chart of soil particle size as shown in Figure 3. The shaded portion of the chart shows the recommended particle size suitable for soil stabilisation, which is in the range of $0 \%$ to $25 \%$ for clay, $0 \%$ to $25 \%$ for silt and 60 to $90 \%$ for sand constituents. In addition, a study by Bengtsson and Whitaker [30] made recommendations for various techniques of soil particle sizes suitable for construction. The values are presented in Table 1.

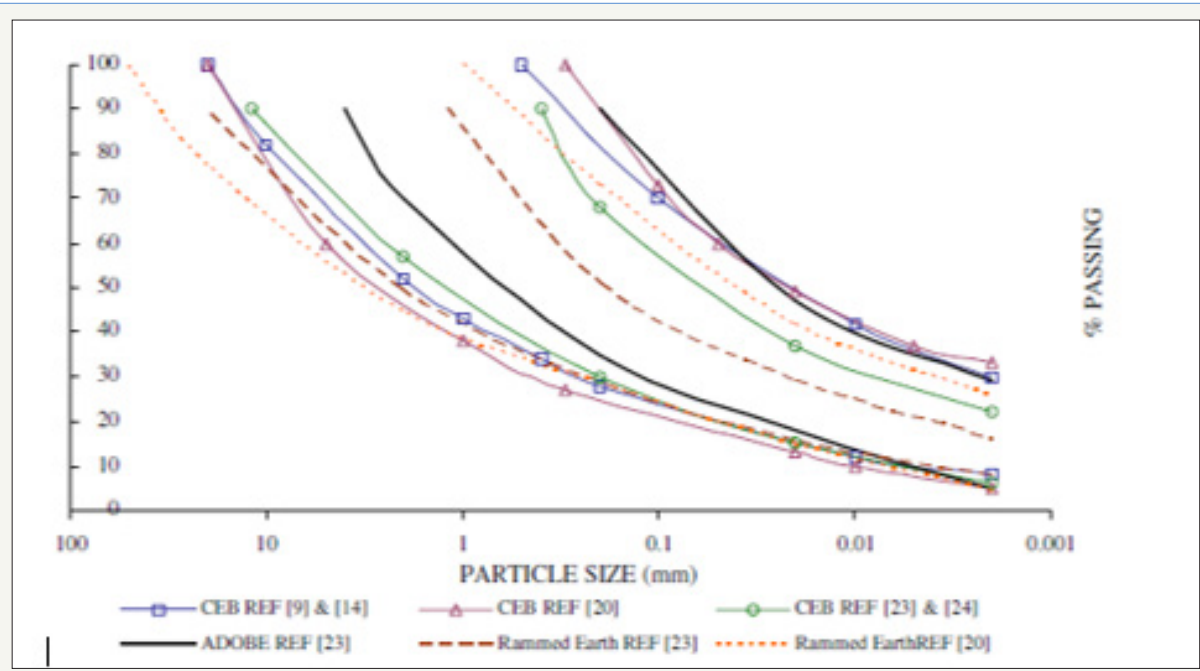

Figure 2: Granularity nomograms [12].

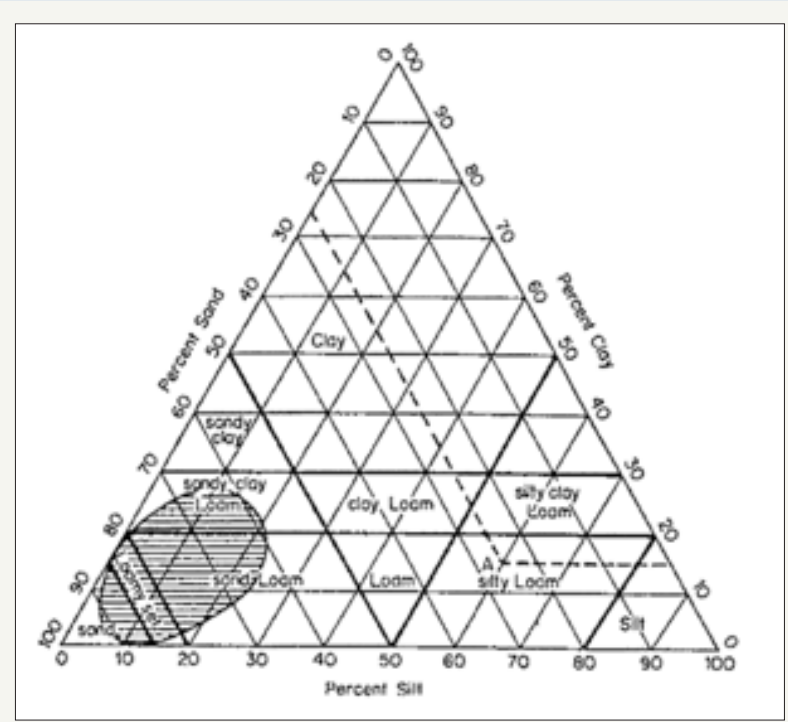

Figure 3: Particle size chart [23]. 
Table 1: Soil grading suitable for construction [30].

\begin{tabular}{|c|c|c|c|c|c|}
\hline Technique & Clay (\%) & Clay \& Silt (\%) & Sand (\%) & Gravel (\%) & Sand \& Gravel (\%) \\
\hline Rammed earth & 20 -May & $15-35$ & $35-80$ & $0-30$ & $50-80$ \\
\hline Pressed soil & $25-$-May & $20-40$ & $40-80$ & $0-20$ & $60-80$ \\
\hline Adobe & $30-0 c t$ & $20-50$ & $50-80$ & - & $50-80$ \\
\hline General purpose & 15 & 35 & 60 & 5 & 65 \\
\hline
\end{tabular}

From Table 1, it is clear that no single recommendation for soil particle size is accepted worldwide as also confirmed by Ciancio et al. [11]. Since there are different types and characteristics of soil at different places, different recommendations are made to provide a suitable grade for construction purposes. One important consideration is that, depending on the soil particle size for the soil to be used for construction, the recommendations could help to identify the appropriate technique and stabiliser to be used in order achieve an optimum result. The results of particle size distribution of 49 soil samples from 36 different studies of published literature are presented in Table 2, showing the clay, silt, sand and gravel contents. The table also shows the recommendations of appropriate technique(s) made for each type of soil based on the soil suitability criteria and requirements. From the soil suitability criteria discussion, the types of soil used in the previous studies could be recommended for the following earth construction techniques: rammed earth (RE), compressed earth blocks (CEB) and adobe blocks (ADO). These recommendations are based on the extreme ends of all the five particles size distribution recommendations for soil suitability criteria discussed above. Another recommendation that can be seen in Table 2 is outside recommendation (OR), which falls outside the criteria for soil suitability for earth construction. It must be noted that the soil samples recommended OR were used in previous studies but are not ideally suitable for construction purposes based on the criteria. This, however, means that the criteria for soil selection may well be imperfect, due to the fact that the soils samples used in some previous studies which produced acceptable results are found to be outside the recommended techniques.

Table 2: Soil particle size distribution of soil samples in previous studies.

\begin{tabular}{|c|c|c|c|c|c|c|c|}
\hline \multirow{2}{*}{ Reference } & \multicolumn{5}{|c|}{ Particle Sizes by Mass (\%) } & \multirow{2}{*}{$\begin{array}{c}\text { Technique } \\
\text { Tested }\end{array}$} & \multirow{2}{*}{$\begin{array}{c}\text { Recommended } \\
\text { Technique }\end{array}$} \\
\hline & Clay & Silt & Fine Sand & Coarse Sand & Gravel & & \\
\hline [6] & 11 & 69 & 20 & & & ADO & $\mathrm{RE} / \mathrm{CEB} / \mathrm{ADO}$ \\
\hline [18] & 21.26 & 24 & 54.74 & & & - & RE/ADO \\
\hline \multirow{2}{*}{$\begin{array}{l}\text { [20] Aga Soil } \\
\text { Ranir Baz Soil }\end{array}$} & 20 & 23.5 & 56.5 & & - & - & CEB/ADO \\
\hline & 28.5 & 42.5 & 29 & & - & - & $\mathrm{RE} / \mathrm{CEB} / \mathrm{ADO}$ \\
\hline$[31]$ & 4.3 & 23.1 & 72.6 & & - & CEB & $\mathrm{RE}$ \\
\hline$[32]$ & 62 & & 30.3 & & 7.7 & ADO & $\mathrm{RE}$ \\
\hline \multirow{2}{*}{$\begin{array}{l}\text { [33] Soil B } \\
\text { Soil Y }\end{array}$} & 48 & 16 & 36 & & - & CEB & $\mathrm{RE}$ \\
\hline & 46 & 24 & 30 & & - & CEB & $\mathrm{RE}$ \\
\hline [34] & 40 & 24 & 35 & & 1 & CEB & $\mathrm{RE}$ \\
\hline$[35]$ & 81 & & 18 & & 1 & ADO & ADO \\
\hline$[36]$ & 16 & 37 & 47 & & - & CEB & ADO \\
\hline [37] & 20 & 33 & 47 & & - & CEB & ADO \\
\hline \multirow{2}{*}{$\begin{array}{c}\text { [38] Soil M } \\
\text { Soil T }\end{array}$} & 48 & 25 & 27 & & - & CEB & OR \\
\hline & 14.5 & 22.5 & 63 & & - & CEB & ADO \\
\hline [39] & 22.4 & 49.9 & 24.5 & & 3.2 & ADO & ADO \\
\hline [40] & 28.5 & 48.5 & 12.7 & & 10.3 & ADO & ADO \\
\hline \multirow{5}{*}{$\begin{array}{r}\text { [41] Soil A1 } \\
\text { Soil A2 } \\
\text { Soil A3 } \\
\text { Soil A4 } \\
\text { Soil A5 }\end{array}$} & 14 & 20 & 66 & & - & ADO & $\mathrm{RE} / \mathrm{ADO}$ \\
\hline & 19 & 28 & 53 & & - & ADO & CEB/ADO \\
\hline & 26 & 23 & 51 & & - & ADO & ADO \\
\hline & 12 & 16 & 72 & & - & ADO & RE/CEB/ADO \\
\hline & 33 & 20 & 47 & & - & ADO & CEB \\
\hline \multirow{3}{*}{$\begin{array}{r}\text { [42] Soil A } \\
\text { Soil B } \\
\text { Soil C }\end{array}$} & 25 & 73 & 2 & & - & CEB & OR \\
\hline & 20 & 65 & 15 & & - & CEB & CEB \\
\hline & 16 & 59 & 25 & & - & CEB & CEB/ADO \\
\hline
\end{tabular}




\begin{tabular}{|c|c|c|c|c|c|c|c|}
\hline [43] & 32.04 & 24.52 & 43.44 & & - & ADO & RE/CEB \\
\hline [44] & 20.87 & 28.96 & 50.17 & & - & ADO & CEB/ADO \\
\hline \multirow{4}{*}{$\begin{array}{r}\text { [45] Soil A } \\
\text { Soil B } \\
\text { Soil C } \\
\text { Soil D }\end{array}$} & 40 & 45 & 8 & 7 & - & ADO & OR \\
\hline & 28 & 29 & 23 & 20 & - & ADO & ADO \\
\hline & 21 & 39 & 5 & 35 & - & ADO & RE/CEB \\
\hline & 26 & 42 & 4 & 27 & - & ADO & RE/CEB \\
\hline$[46]$ & 25 & 61.8 & 13.2 & & - & CEB & CEB/ADO \\
\hline [47] & 12 & 16 & 64 & & 8 & CEB & RE/ADO \\
\hline [48] & 14 & 28 & 46 & & 12 & CEB & RE/ADO \\
\hline [49] & 16 & 35 & 42 & & 7 & CEB & RE/ADO \\
\hline$[50]$ & 33 & 22 & 37 & & 8 & CEB & RE/CEB \\
\hline \multirow{2}{*}{$\begin{array}{r}\text { [51] Soil } 1 \\
\text { Soil } 2\end{array}$} & 16 & 35 & 42 & & 7 & CEB & RE/ADO \\
\hline & 30 & 48 & 22 & & - & CEB & CEB/ADO \\
\hline [52] & 16 & 46 & 33 & & - & ADO & RE/ADO \\
\hline [53] & 10 & 5 & 85 & & - & ADO & RE/ADO \\
\hline [54] & 32 & 45 & 22.5 & & - & ADO & $\mathrm{RE} / \mathrm{CEB} / \mathrm{ADO}$ \\
\hline [55] & 0.50 & 51.50 & 40.7 & 7.30 & - & ADO & OR \\
\hline [56] & 10 & 87 & 3 & & & CEB & OR \\
\hline [57] & 12.2 & 1.5 & 87.3 & & - & CEB & OR \\
\hline [58] & 25.5 & 30 & 44.5 & & - & ADO & CEB \\
\hline [59] & 31.3 & 67 & 1.7 & & - & ADO & OR \\
\hline$[60]$ & 3.4 & 13 & 83 & & - & ADO & OR \\
\hline$[61]$ & 67 & 30 & 3 & & - & - & OR \\
\hline$[62]$ & 8 & 84 & 8 & & - & CEB & OR \\
\hline [63] & 13.63 & & 84.8 & & 1.57 & CEB & OR \\
\hline
\end{tabular}

*RE: Rammed Earth; CEB: Compressed Earth Block; ADO: Adobe; OR: Outside Recommendation

Studies $[18,20,61]$ did not state clearly the earth construction technique that was used. From the results, soil samples used in studies [31-34] were within the recommended soil technique for only RE. Some of the soil samples used in studies [35-41] were found within the recommended soil technique for only ADO. Again, soil samples used in studies [41,42] were found within the recommended Some of the soil samples technique for only CEB. These soil samples from previous studies were identified to be suitable for only one earth construction technique. However, there are other soil samples in previous studies that could be recommended for two different techniques of earth construction. Examples are soil samples used in studies [41-53]. Some of the soil samples from the previous studies [54] could further be recommended for use for three different techniques of earth construction. This implies that some soil types are such that they could be applicable in three different techniques for earth construction. It could, therefore, be said that any type of soil that is found to be suitable for construction purposes can be applied for between one and three techniques of earth construction, with the majority for only one technique.

However, the results show that some of the soil particle sizes were found to be outside the criteria of suitability of the soil for earth construction $[38,42,45,55-57,59,60-62]$. Soil samples from these studies were found to contain limited clay or sand content, or excessive quantities of sand, clay, silt or clay+silt. Though these soil samples were found to be outside the recommendation, some stabilisers were added to the soil to improve their geotechnical properties. This means that, though some soil samples may be found to be unsuitable for construction purpose, they can still be used not in raw state but with the addition of stabiliser(s). Table 1 also shows clearly that the earth techniques which were adopted in the studies in which the soil samples were used are different from the recommended techniques. This situation happened because researchers usually do not measure the particle size distribution of their soil samples in order to determine their suitability for the technique to be used. But rather, they measure the particles size distribution of their soil sample for the purpose of determining the geotechnical properties in order to describe the soil used in their study.

\section{Atterberg limits}

Atterberg limits test estimates the clay minerals that are present in the soil [64]. It can provide a means for objectively and broadly classifying a soil for a given location [65]. For construction purposes, determining the liquid and plastic limits out of the other limits are sufficient. Therefore, the other limits are not important 
[64] because the tests are undertaken on small remoulded samples of only the fraction of the required sample that passes through a $425 \mu \mathrm{m}$ sieve. Plastic limit $\left(W_{\mathrm{p}}\right)$ can be defined as the moisture content at which a soil will begin to crumble when rolled into a thread of about $3 \mathrm{~mm}$ in diameter [66]. Liquid limit $\left(W_{\mathrm{L}}\right)$ is the moisture content at which the soil changes from plastic to liquid states and begins to flow [67]. Plasticity index $\left(I_{p}\right)$ is the difference between the plastic limit and the liquid limit $\left(w_{\mathrm{p}-} w_{\mathrm{L}=} I_{p}\right)$.

Three criteria from six (6) studies are presented in Figure 4-6 and are discussed for their suitable application as earth material for building purposes. Figure 4 presents a chart of Atterberg limits which was originally developed by Doat et al. [22] and later used by Stulz and Mukerji [64] and Norton [68] for determining the suitability of soil that needs binder in order to function satisfactorily as a building material. It shows the various zones within which different stabilisers (lime, cement and bitumen) should be used as an enhancement. This means some types of soil are unsuitable for building houses, while some will need certain stabilisers to improve their geotechnical properties. It should be noted that laterite soils do not necessarily conform to this chart [64] due to laterite suitability for building purposes without the need for any stabilization. The limits are between plasticity index of 7 to $29 \%$ and liquid limit of 25 to $50 \%$ for cement stabilised soil, while for lime they are between plasticity index of 18 to $29 \%$ and liquid limit of 35 to $50 \%$. For bitumen, they are between plasticity index of 2.5 to $13 \%$ and liquid limit of 25 to $35 \%$.

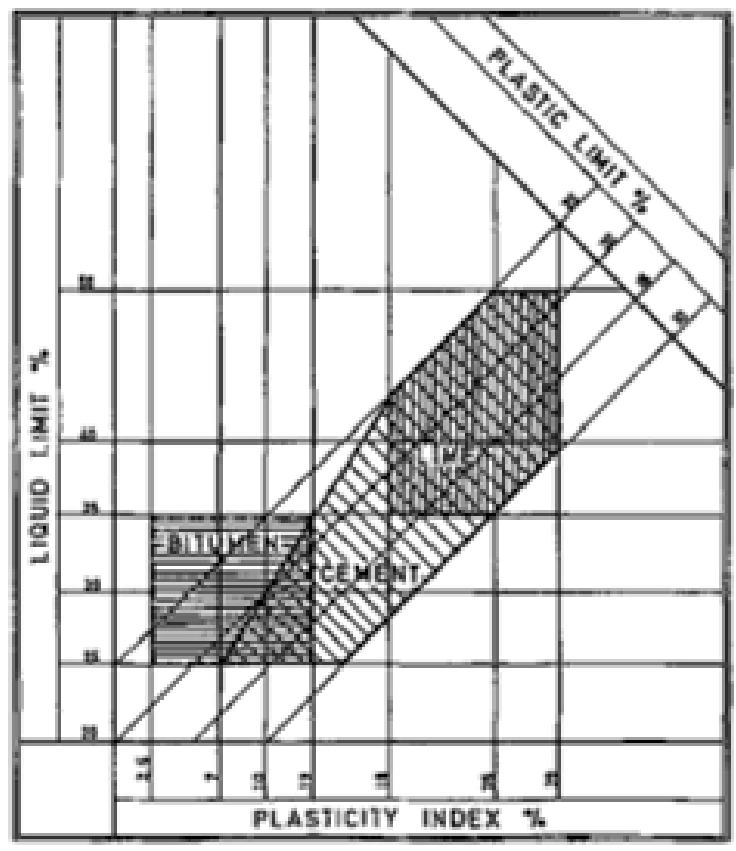

Figure 4: Atterberg limits chart [22].

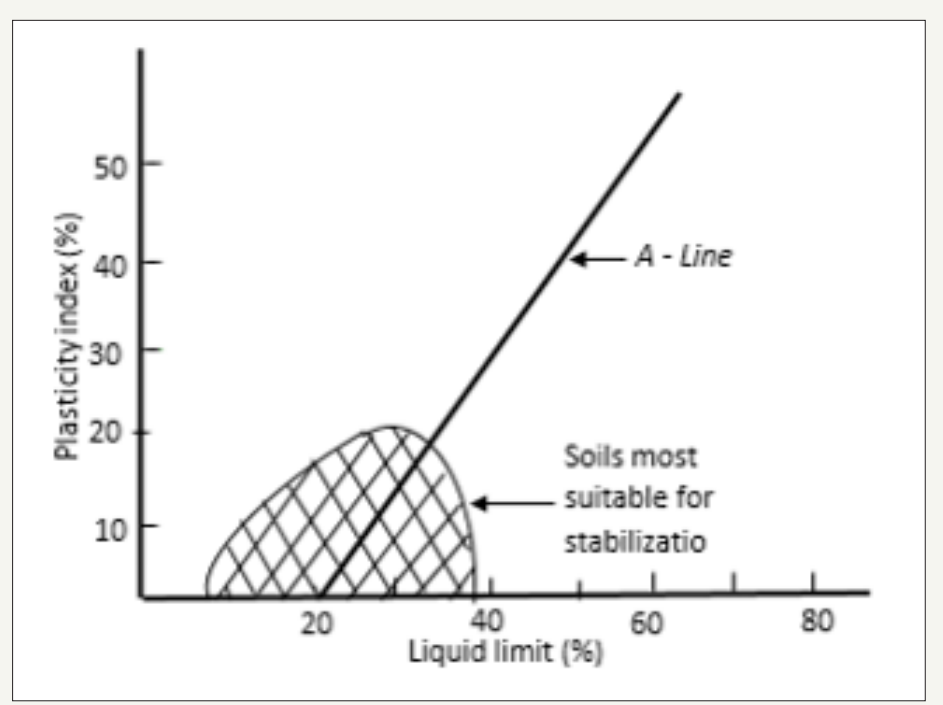

Figure 5: Plasticity chart [23]. 


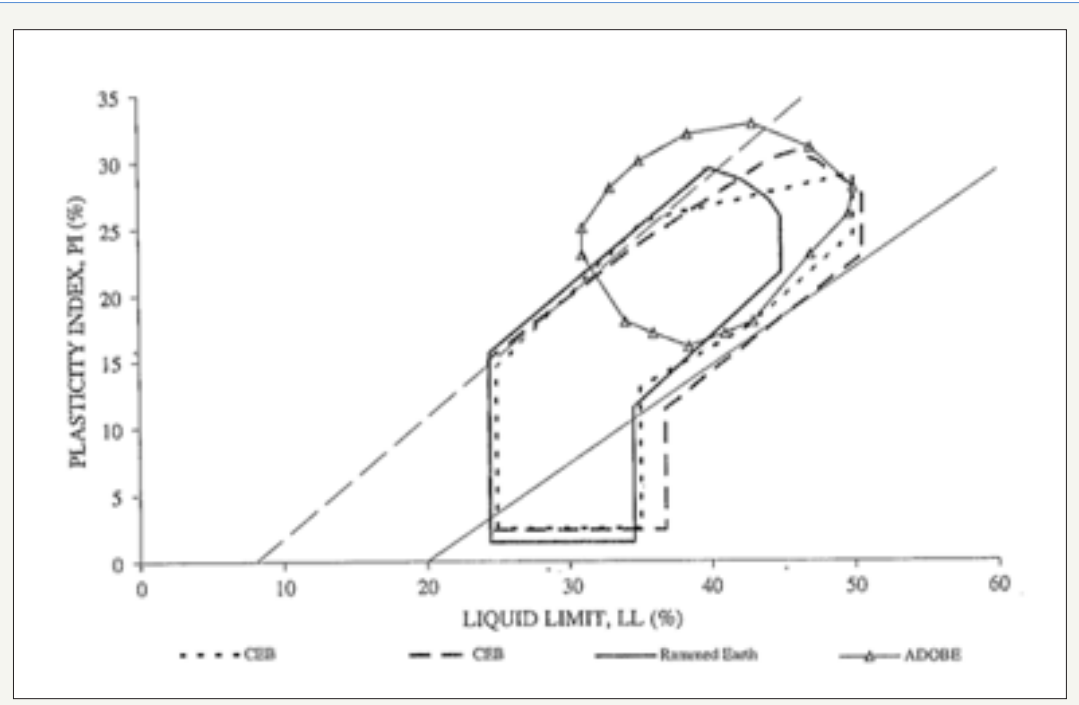

Figure 6: Plasticity nomograms [12].

Spence and Cook [23] also proposed an Atterberg limits zone of soil suitability for stabilisation for soil as shown in the shaded area in Figure 5. The limits are between plasticity index 0 to $22 \%$ and liquid limit between 7 to $39 \%$. These limits are different from Doat et al. [22] limits. The reason for the difference is that Spence and Cook [23] gave a recommendation of soil for general stabilisation while Doat et al. [22] recommendation had separate soil suitability for cement, lime and bitumen. The study by Delgado and Guerrero [12] presented a nomogram plasticity index chart showing the recommended values for three soil techniques (Figure 6). CEB technique was recommended by AFNOR [29], CRATerre-EAG [28] \& Houben and Guillaud [27], while RE and adobe techniques were recommended by Houben and Guillaud [27]. However, Delgado and Guerrero [12] recommended a plasticity index of 16 to $28 \%$ and liquid limit of 32 to $46 \%$ as a good soil for earth construction techniques.

Table 3 presents the results of Atterberg limits of 53 soil samples from 42 studies of published articles. It shows the liquid limits, plastic studies of limits and plasticity index of soil samples used in the previous studies. In addition, recommendations of appropriate technique(s) for each soil sample are made based on the plasticity index criteria discussed above. The recommended techniques are based on the extreme ends of all the three Atterberg limits recommendations for soil suitability criteria discussed. As discussed above, the recommendations are based on the available techniques for earth construction such as RE, ADO and CEB. The recommendations made also considered OR as some of the soil samples were found to be outside the recommended soil suitability.

Previous studies [18-20,61] did not state clearly the earth construction technique that was used. The soil samples used in studies $[18,20,55,69,70]$ were found to be within the recommended soil technique for only RE. Soil samples from studies $[34,47,48,62]$ were within the recommended soil technique for only ADO. Furthermore, soil samples used in studies $[32,37,38]$ were within the recommended soil technique for only CEB. These results indicate the suitability of soil types for only one technique of earth construction. There were a number of soil samples in previous studies that could be recommended for two techniques of earth construction, such as soil samples used in studies $[6,7,19,33,38$, $39,45,46,54,71-77]$. Other soil samples from the previous studies could be recommended to be used for three techniques of earth construction $[44,45,49,51,58,59,63,73]$. This suggests again that some soil types could be used for three different techniques for earth construction. This confirms the earlier accession that any type of soil that is found to be suitable for construction purposes can be applied for between one and three techniques of earth construction.

Conversely, some of the Atterberg limits in the previous studies $[33,35,36,42,45,49,51,61,75,79,80]$ were found to be outside the criteria for suitability of the soil for earth construction. Soil samples from these studies were found to have either high liquid limit $\left(W_{\mathrm{L}}>50\right)$ or high plasticity index $\left(I_{\mathrm{p}}>30\right)$. Again, the addition of stabilisers could improve the geotechnical properties of soil samples that are outside the recommendation. A suitable raw soil for earth construction should contain sufficient amount of particle sizes to prevent damage to the material such as excessive shrinkage, swelling, cracking and bond failure. The clay content in soil is a major factor in earth construction since it binds the larger particles together. However, soils with more than $30 \%$ clay have very high shrinkage and swelling effect, together with their tendency to absorb moisture, which may result in the development of cracks in the end product. Equally, a very low content of clay in the soil will also result in poor bonding of the other particles, which may cause bound failure in the end product. Therefore, soil with very low or very high content of clay and sometimes silt may need the inclusion of stabilisers in order to be suitable for construction purposes.

Careful observation of the particle size distribution and Atterberg limits results in Tables 2 \& 3 show that some of the soil samples found to be suitable for a particular test were unsuitable for the other tests. For example, the soil sample used in the study by Achenza and Fenu [55] was found to be suitable in Atterberg limits result but was unsuitable in the particle size distribution result. Similarly, the soil sample used in the study by Degirmenci [35] was found to be suitable in the particle size distribution result but was 
unsuitable in the Atterberg limits result. Another observation is that some of the soil samples recommended for a particular technique in one test could be to be recommended for a different technique in another test. An example is the soil sample used in the study by Muntohar [37] which was recommended for ADO technique in the particle size distribution result, while the same soil sample was recommended for CEB technique in the Atterberg limits result. This, therefore, means that soil suitability for earth construction cannot be determined by using only one test, but a number of tests. And if any of the tests are found to be outside recommendation, then the use of stabiliser becomes necessary.

Table 3: Atterberg limits of soil samples in previous studies.

\begin{tabular}{|c|c|c|c|c|c|}
\hline \multirow{2}{*}{ Reference } & \multicolumn{3}{|c|}{ Atterberg Limits } & \multirow{2}{*}{ Technique Tested } & \multirow{2}{*}{ Recommended Technique } \\
\hline & $W_{\mathrm{L}}(\%)$ & $W_{\mathrm{P}}(\%)$ & $I_{\mathrm{P}}$ & & \\
\hline$[6]$ & 29.1 & 17.4 & 11.7 & ADO & $\mathrm{RE} / \mathrm{CEB}$ \\
\hline$[7]$ & 49.2 & 26.9 & 22.3 & CEB & $\mathrm{RE} / \mathrm{CEB}$ \\
\hline$[18]$ & 25.76 & 20.2 & 5.56 & - & $\mathrm{RE}$ \\
\hline [19] & 38.2 & 23.4 & 14.8 & - & $\mathrm{RE} / \mathrm{CEB}$ \\
\hline \multirow{2}{*}{$\begin{array}{l}\text { [20] Aga Soil } \\
\text { Ranir Bazar soil }\end{array}$} & 23 & 17.64 & 5.36 & - & $\mathrm{RE}$ \\
\hline & 29.9 & 17.3 & 12.6 & - & $\mathrm{RE} / \mathrm{CEB}$ \\
\hline$[31]$ & 25.28 & 13.28 & 12 & CEB & $\mathrm{RE} / \mathrm{CEB}$ \\
\hline [32] & 39 & 24 & 15 & ADO & CEB \\
\hline \multirow{2}{*}{$\begin{array}{r}\text { [33] Soil B } \\
\text { Soil Y }\end{array}$} & 48.4 & 23.2 & 25.2 & CEB & $\mathrm{RE} / \mathrm{CEB}$ \\
\hline & 62.93 & 24.74 & 38.2 & CEB & OR \\
\hline$[34]$ & 45.11 & 31.56 & 13.6 & CEB & ADO \\
\hline [35] & 56.41 & 35.71 & 20.7 & ADO & OR \\
\hline [36] & 63 & 32 & 31 & CEB & OR \\
\hline [37] & 41 & 25 & 16 & CEB & CEB \\
\hline \multirow{2}{*}{$\begin{array}{c}\text { [38] Soil M } \\
\text { Soil T }\end{array}$} & 31 & 19 & 12 & CEB & $\mathrm{RE} / \mathrm{CEB}$ \\
\hline & 50 & 24 & 26 & CEB & CEB \\
\hline [39] & 26.4 & 18.4 & 8 & ADO & $\mathrm{RE} / \mathrm{CEB}$ \\
\hline \multirow{3}{*}{$\begin{array}{r}\text { [42] Soil A } \\
\text { Soil B } \\
\text { Soil C }\end{array}$} & 65 & 35 & 30 & CEB & OR \\
\hline & 62 & 35 & 27 & CEB & OR \\
\hline & 65 & 42 & 23 & CEB & OR \\
\hline$[44]$ & 37.5 & 20 & 17.5 & ADO & $\mathrm{RE} / \mathrm{CEB} / \mathrm{ADO}$ \\
\hline \multirow{4}{*}{$\begin{array}{c}\text { [45] Soil A } \\
\text { Soil B } \\
\text { Soil C } \\
\text { Soil D }\end{array}$} & 56.76 & 23.43 & 33 & ADO & OR \\
\hline & 32.72 & 14.94 & 18 & ADO & $\mathrm{RE} / \mathrm{CEB}$ \\
\hline & 31.63 & 17.82 & 14 & ADO & RE/CEB \\
\hline & 39.67 & 21.85 & 18 & ADO & RE/CEB/ADO \\
\hline [46] & 34.5 & 16.9 & 17.6 & CEB & $\mathrm{RE} / \mathrm{CEB}$ \\
\hline [47] & 18 & 31.7 & 13.7 & CEB & ADO \\
\hline [48] & 13.3 & 27.2 & 13.9 & CEB & ADO \\
\hline \multirow{2}{*}{$\begin{array}{r}\text { [49] Soil } 1 \\
\text { Soil } 2\end{array}$} & 39 & 20 & 19 & CEB & $\mathrm{RE} / \mathrm{CEB} / \mathrm{ADO}$ \\
\hline & 52 & 23 & 29 & CEB & OR \\
\hline$[51]$ & 39 & 20 & 19 & CEB & $\mathrm{RE} / \mathrm{CEB} / \mathrm{ADO}$ \\
\hline$[52]$ & 24 & 16 & 8 & ADO & $\mathrm{RE} / \mathrm{CEB}$ \\
\hline [54] & 34.8 & 19.1 & 15.7 & ADO & $\mathrm{RE} / \mathrm{CEB}$ \\
\hline [55] & 24 & 21 & 3 & ADO & $\mathrm{RE}$ \\
\hline [58] & 38 & 20 & 18 & ADO & RE/CEB/ADO \\
\hline [59] & 36.4 & 18.6 & 17.8 & ADO & RE/CEB/ADO \\
\hline$[61]$ & 90 & 36 & 54 & - & OR \\
\hline
\end{tabular}




\begin{tabular}{|c|c|c|c|c|c|}
\hline [62] & 46.1 & 29.4 & 16.7 & CEB & ADO \\
\hline [63] & 35 & 17 & 18 & CEB & RE/CEB/ADO \\
\hline [69] & 27 & 19 & 8 & $\mathrm{RE}$ & $\mathrm{RE}$ \\
\hline [70] & 23.29 & 17.79 & 5.51 & ADO & $\mathrm{RE}$ \\
\hline [71] & 28 & 17 & 11 & $\mathrm{ADO}$ & RE/CEB \\
\hline [72] & 45.85 & 22.38 & 23.5 & CEB & CEB/ADO \\
\hline \multirow{2}{*}{$\begin{array}{c}\text { [73] Soil A } \\
\text { Soil U }\end{array}$} & 33 & 18 & 15 & CEB & RE/CEB \\
\hline & 35 & 21 & 14 & CEB & $\mathrm{RE} / \mathrm{CEB}$ \\
\hline [74] & 41.3 & 25.2 & 16.1 & $\mathrm{ADO}$ & $\mathrm{RE} / \mathrm{CEB}$ \\
\hline \multirow{2}{*}{$\begin{array}{r}\text { [75] TS } \\
\mathrm{TM}\end{array}$} & 30 & 21 & 9 & CEB & RE/CEB \\
\hline & 60 & 29 & 31 & CEB & $\mathrm{OR}$ \\
\hline [76] & 36.7 & 24.5 & 12.2 & $\mathrm{ADO}$ & $\mathrm{RE} / \mathrm{CEB}$ \\
\hline [77] & 35 & 24 & 11 & $\mathrm{ADO}$ & RE/CEB \\
\hline [78] & 38 & 20 & 18 & CEB & RE/CEB/ADO \\
\hline [79] & 50 & 18.33 & 31.7 & $\mathrm{ADO}$ & OR \\
\hline$[80]$ & 67 & 35 & 32 & CEB & OR \\
\hline
\end{tabular}

$\mathrm{W}_{\mathrm{L}}$ : Liquid Limit; $\mathrm{W}_{\mathrm{P}}$ : Plastic Limit; $\mathrm{I}_{\mathrm{P}}$ : Plastic Index; RE: Rammed Earth; CEB: Compressed Earth Block; ADO: Adobe; OR: Outside Recommendation

\section{Specific gravity, optimum moisture content and maxi- mum dry density}

The specific gravity of a soil is used in relating a weight of soil to its volume and in the calculation of phase relationship, i.e. the relative volume of solids to water and air in a given volume of soil [81]. Specific gravity $\left(G_{S}\right)$ of a solid substance is the ratio of the weight of a given volume of material to the weight of an equal volume of water at $20{ }^{\circ} \mathrm{C}$ [24]. In simple language, the specific gravity of soil tells how much heavier or lighter in weight the soil is than water. In many situations during construction processes, it is necessary for the soil to be compacted to its maximum dry density [82]. Compaction is the process of mechanically densifying a soil by pressing the soil particles together into a closed state of contact so that the entrapped air can be expelled from the soil mass $[83,84]$. The relationship between the maximum dry density of soil and optimum moisture content can be obtained from soil compaction from standard Proctor test, and this relationship helps in determining the optimum water content at which maximum dry density of soil can be attained through compaction [85-89]. Optimum moisture content (OMC) of soil is the water content at which a maximum dry density of soil can be achieved after compaction. Maximum dry density (MDD) of soil is the density obtained by the compaction of soil at its optimum moisture content.

Table 4 presents the data collected from previously published articles on specific gravity, optimum moisture content and maximum dry density of soil samples used in their investigation. Twentyseven (27) soil samples from 21 studies reported the details of the specific gravity of the soil samples used in their investigation. It can be seen from the Table 4 that with the exception of two studies [31-78], all the others obtained specific gravity of between 2.00 and 2.80 as recommended by FM5-472 [31-78]. Alavéz Ramírez et al. [31] obtained a specific gravity of 1.82 , which was below the recommendation and Millogo et al. [78] had a specific gravity of 3.02 which was above the recommendation.

Table 4: Specific gravity, optimum moisture content and maximum dry density of soil samples in previous studies.

\begin{tabular}{|c|c|c|c|}
\hline Source & $\mathbf{G}_{\mathbf{s}}$ & $\mathbf{( O M C )} \mathbf{( \% )}$ & $\mathbf{( M D D )} /\left(\mathrm{g} / \mathbf{c m}^{3}\right)$ \\
\hline$[6]$ & 2.5 & - & 1.83 \\
\hline$[18]$ & 2.57 & - & 1.89 \\
\hline$[19]$ & - & 14 & 1.79 \\
\hline$[20]$ Aga soil & 2.58 & 17.8 & 1.69 \\
\hline Ranir Bazar soil & 2.57 & 9.4 & 1.98 \\
\hline$[31]$ & $1.82^{*}$ & 11 & 1.76 \\
\hline$[32]$ & - & 16.6 & 1.86 \\
\hline [33] Soil B & - & 18.8 & 1.94 \\
\hline
\end{tabular}




\begin{tabular}{|c|c|c|c|}
\hline [35] & 2.44 & $37.70^{*}$ & 1.36 \\
\hline [36] & 2.66 & - & - \\
\hline [42] Soil A & 2.63 & 26 & 1.36 \\
\hline Soil B & 2.68 & 25 & 1.37 \\
\hline Soil C & 2.6 & 26 & 1.38 \\
\hline$[44]$ & 2.55 & - & - \\
\hline [45] Soil A & 2.7 & - & - \\
\hline Soil B & 2.68 & - & - \\
\hline Soil C & 2.72 & - & - \\
\hline Soil D & 2.67 & - & - \\
\hline [47] & & 11.8 & 1.83 \\
\hline [48] & - & 18 & 1.78 \\
\hline [52] & 2.5 & - & - \\
\hline [55] & 2.64 & - & - \\
\hline [57] & - & 9 & 1.78 \\
\hline [59] & 2.7 & 16.5 & 1.7 \\
\hline [61] & 2.08 & 29 & 1.45 \\
\hline [62] & 2.47 & - & \\
\hline [70] & 2.67 & 12.5 & 1.88 \\
\hline [72] & 2.71 & & \\
\hline [74] & 2.69 & 25.15 & 1.5 \\
\hline [76] & 2.72 & 22.42 & - \\
\hline [77] & - & 12 & 1.76 \\
\hline [78] & $3.02^{*}$ & - & 1.06 \\
\hline [79] & 2.28 & 29.8 & 1.43 \\
\hline [80] & - & 29 & 1.42 \\
\hline [86] & 2.65 & - & - \\
\hline [87] & - & 12 & 1.83 \\
\hline
\end{tabular}

SG: Specific Gravity; OMC: Optimum Moisture Content; MDD: Maximum Dry Density

\section{*=Outside recommendation}

Table 4 also shows the optimum moisture content values of 23 soil samples from 19 studies. Because there are no known criteria for acceptable optimum moisture content, the study considered values that are closely related as suitable optimum moisture content. It can be observed from the table that values between 09.00 and $29.80 \%$ were closely related with a spacing of not more than $3.00 \%$. Therefore, per the available data in the table, the study recommends suitable optimum moisture content of between 09.00 and 29.80. It can be seen from the result that, with the exception of the study by Degirmenci [35], all the other soil samples were within the recommendation. The soil sample in the study [35] recorded an optimum moisture content of $37.70 \%$ which is far beyond the recommendation. Thirty-seven (37) soil samples from 30 studies are also shown in Table 4 for their maximum dry density. The values obtained are between 1.06 and $1.94 \mathrm{~g} / \mathrm{cm}^{3}$. Critical observation of all the values shows a closely related spacing among them.
This, therefore, provides the basis for recommendation for all the maximum dry density values in the table. Considering the results of the specific gravity, optimum moisture content and maximum dry density of soil samples, it can be noted that their influence in determining the suitability of the soil for earth construction is less as compared with the particle size distribution and Atterberg limits.

\section{Summary and Conclusion}

This study compiled the previous published studies' soil samples and compare them with soil suitability criteria for recommending suitable soil for earth construction purposes. Based on the soil properties found in literature, recommendations were made for the suitability of different soil samples for three main techniques (adobe, rammed earth and compressed earth blocks) application in earth construction, while other soil samples were found to be outside the recommendations. It was found that 
some of the earth construction techniques which were adopted in the previous studies in which the soil samples were used are different from the recommended techniques because researchers usually do not determine the particle size distribution of their soil samples before adopting the appropriate technique to use. It was also observed that some of the soil samples found to be suitable in one test were unsuitable for the other tests, and again, some of the soil samples recommended for a particular technique in one test were recommended for a different technique in another test. From the foregoing, the study suggests that a number of tests should be conducted on soil sample for earth construction, and if any of the tests are found to be outside recommendation, then the use of stabiliser becomes necessary. In view of this, the study concludes that determining the suitability of the soil for earth construction is important and any soil that is found unsuitable should be enhanced with stabilisers before use for earth construction.

\section{Data Availability}

The data used to support the findings of this study are available from the corresponding author upon request.

\section{References}

1. https://www.smartshelterfoundation.org/wp-content/ uploads/2014/07/SSF-soil-testing-manual.pdf

2. Stavridakis EI (2006) A Solution to the problem of predicting the suitability of silty-clayey materials for cement-stabilization. Geotechnical \& Geological Engineering.

3. https://nacto.org/docs/usdg/evaluation_of_urban_soils_epa.pdf

4. Bryan AJ (1988) Criteria for the suitability of soil for cement stabilization Building and Environment 23(4): 309-319.

5. Parisi F, Asprone D, Fenu L, Prota A (2015) Experimental characterization of Italian composite ad obe bricks reinforced with straw fibers. Composite Structures 122: 300-307.

6. Araya Letelier G, Concha Riede J, Antico FC, Valdés C, Cáceres G (2018) Influence of natural fiber dosage and length on adobe mixes damagemechanical behaviour, Construction and Building Materials 174: 645655.

7. Danso H (2017) Experimental Investigation on the Properties of Compressed Earth Blocks Stabilised with a Liquid Chemical. Advances in Materials 6(6): 122-128

8. Laborel Préneron A, Aubert JE, Magniont C, Tribout C, Bertron A (2016) Plant aggregates and fibers in earth construction materials: A review. Construction and Building Materials 111: 719-734.

9. Tharaka DGS, Mampearachchi WK (2012) Suitability of cohesionless soil as a highway construction material. civil engineering research exchange symposium, Faculty of Engineering University of Ruhuna, Sri Lanka.

10. Hamard E, Cazacliu B, Razakamanantsoa A, Morel JC (2016) Cob, a vernacular earth construction process in the context of modern sustainable building. Building and Environment 106: 103-119.

11. Ciancio D, Jaquin P, Walker P (2013) Advances on the assessment of soil suitability for rammed earth. Construction and Building Materials 42 40-47.

12. Delgado MCJ, Guerrero IC (2007) The selection of soils for unstabilised earth building: A normative review. Construction and Building Materials 21(2): 237-251.

13. Roy S, Bhalla SK (2017) Role of geotechnical properties of soil on civil engineering structures. Resources and Environment 7(4): 103-109.

14. Adegun OB, Adedeji YMD (2017) Review of economic and environmen- tal benefits of earthen materials for housing in Africa. Frontiers of Architectural Research 6(4): 519-528.

15. Danso H, Martinson B, Ali M, Mant C (2015) Performance characteristics of enhanced soil blocks: A quantitative review. Building Research \& Information 43(2): 253-262.

16. Ciancio D, Jaquin P (2011) An overview of some current recommendations on the suitability of soils for rammed earth. International Symposium on Innovation \& Sustainability of Structures in Civil Engineering, Xiamen University, China.

17. Maniatidis V, Walker P (2003) A review of rammed earth construction for DTi partners in innovation project 'developing rammed earth for UK housing

18. http://www.ejge.com/2012/Ppr12.261alr.pdf

19. Zhang J, Weng XZ, Liu JZ (2018) Strength and water stability of a fiberreinforced cemented loess. Journal of Engineered Fibers and Fabrics 13(1): 72-83.

20. http://www.ijetsr.com/images/short_pdf/1503855009_874-886mccia833_ijetsr_n.pdf

21. Danso H (2015) Use of agricultural waste fibres as enhancement of soil blocks for low-cost housing in Ghana [Ph.D. thesis], School of Civil Engineering and Surveying, University of Portsmouth, England.

22. Doat P, Hays A, Houben H, Matuk S, Vitoux F (1979) Construire en Terre. CRATerre, Paris.

23. Spence RJS, Cook DJ (1983) Building materials in developing countries. Chichester, Wiley, England.

24. https://www.globalsecurity.org/military/library/policy/army/fm/5472/ch2part2.pdf

25. Jillavenkatesa A, Dapkunas SJ, Lin Sien L (2001) Particle size characterization. NIST Special Publication, pp. 960-961.

26. Gooding DEM (1993) Soil testing for soil-cement block preparation Development Technology Unit working paper, volume 38.

27. Houben H, Guillaud H (1994) Earth construction: A comprehensive guide. Intermediate Technology Publications, London.

28. CRATerre EAG (1998) Compressed earth blocks: Standards-Technology series, no. 11, Brussels, CDI.

29. AFNOR XP (2001) Compressed earth blocks for walls and partitions: Definitions-Specifications-Test methods-Delivery acceptance conditions. Saint-Denis La Plaine Cedex.

30. Bengtsson LP, Whitaker JH (1986) Farm structures in tropical climates. FAO/SIDA Cooperation Programme, Rome, Italy.

31. Alavéz Ramírez R, Montes Garcia P, Martinez Reyes J, Altamirano Juarez DC, Gochi Ponce Y (2012) The use of sugarcane bagasse ash and lime to improve the durability and mechanical properties of compacted soil blocks. Construction and Building Materials 34: 296-305

32. Bahar R, Benazzoug M, Kenai S (2004) Performance of compacted cement-stabilised soil. Cement \& Concrete Composites 26: 811-820.

33. Elenga RG, Mabiala B, Ahouet L, Goma Maniongui J, Dirras GF (2011) Characterization of clayey soils from congo and physical properties of their compressed earth blocks reinforced with post-consumer plastic wastes. Geomaterials 1: 88-94.

34. Medjo Eko R, Offa ED, Ngatcha TY, Minsili LS (2012) Potential of salvaged steel fibers for reinforcement of unfired earth blocks. Construction and Building Materials 35: 340-346

35. Degirmenci N (2008) The using of waste phosphogypsum and natural gypsum in adobe stabilization. Construction and Building Materials 22(6): 1220-1224.

36. Ismail S, Yaacob Z (2011) Properties of laterite brick reinforced with oil palm empty fruit bunch fibers. Pertanika Journal of Science and Technology 19(1): 33-43. 
37. Muntohar AS (2011) Engineering characteristics of the compressedstabilized earth brick. Construction and Building Materials 25(11): 4215-4220.

38. Ngowi AB (1997) Improving the traditional earth construction: a case study of Botswana. Construction and Building Materials 11(1): 1-7.

39. Piattoni Q Quagliarini E, Lenci S (2011) Experimental analysis and modelling of the mechanical behaviour of earthen bricks. Construction and Building Materials 25(4): 2067-2075.

40. Quagliarini W, Lenci S (2010) The influence of natural stabilizers and natural fibres on the mechanical properties of ancient Roman adobe bricks. Journal of Cultural Heritage 11(3): 309-314.

41. Yetgin S, Cavdar 0, Cavdar A (2008) The effects of the fiber contents on the mechanic properties of the adobes. Construction and Building Materials 22(3): 222-227.

42. Akbulut S, Arasan S, Kalkan E (2007) Modification of clayey soils using scrap tire rubber and synthetic fibers. Applied Clay Science 38(1-2): 2332.

43. Binici H, Aksogan O, Shah T (2005) Investigation of fibre reinforced mud brick as a building material. Construction and Building Materials 19(4): 313-318.

44. Bhatta B (2010) Analysis of urban growth and sprawl from remote sensing data. Advances in geographic information science series Heidelberg, Springer, New York, USA.

45. Bouhicha M, Aouissi F, Kenai S (2005) Performance of composite soil reinforced with barley straw. Cement \& Concrete Composites 27(5): 617-621.

46. Cai Y, Shi B, Ng CWW, Tang C (2006) Effect of polypropylene fibre and lime admixture on engineering properties of clayey soil. Engineering Geology 87(3-4): 230-240.

47. Danso H, Martinson DB, Ali M, Williams JB (2017) Mechanisms by which the inclusion of natural fibres enhance the properties of soil blocks for construction. Journal of Composite Materials 51(27): 3835-3845.

48. Danso H, Martinson DB, Ali M, Williams J (2015) Effect of fibre aspect ratio on mechanical properties of soil building blocks. Construction and Building Materials 83: 314-319.

49. Hossain KMA, Mol L (2011) Some engineering properties of stabilized clayey soils incorporating natural pozzolans and industrial wastes. Construction and Building Materials 25(8): 3495-3501.

50. Danso H (2017) Improving water resistance of compressed earth blocks enhanced with different natural fibres. The Open Construction and Building Technology Journal 11: 433-440.

51. Hossain KMA, Lachemi M, Easa S (2007) Stabilized soils for construction applications incorporating natural resources of Papua New Guinea. Resources, Conservation and Recycling 51(4): 711-731.

52. Maskell D, Heath A, Walker P (2015) Use of metakaolin with stabilized extruded earth masonry units. Construction and Building Materials 78 172-180.

53. Vilane BRT (2010) Assessment of stabilization of adobes by confined compression tests. Biosystems Engineering 106(4): 551-558.

54. Gala'n Marı́n C, Rivera Go'mez C, Petric J (2010) Clay-based composite stabilized with natural polymer and fibre. Construction and Building Materials 24(8): 1462-1468.

55. Achenza M, Fenu L (2006) On earth stabilization with natural polymers for earth masonry construction. Materials and Structures 39(1): 21-27.

56. Arumala JO, Gondal T (2007) Compressed earth building block for affordable housing. RICS Publishers, London, UK.

57. Donkor P, Obonyo E (2016) Compressed soil blocks: influence of fibers on flexural properties and failure mechanism. Construction and Building Materials 121: 25-33.

58. Kouakou CH, Morel JC (2009) Strength and elastoplastic properties of non-industrial building materials manufactured with clay as a natural binder. Applied Clay Science 44(1-2): 27-34.

59. Li J, Tang C, Wang D, Pei X, Shi B (2014) Effect of discrete fibre reinforcement on soil tensile strength. Journal of Rock Mechanics and Geotechnical Engineering 6(2): 133-137.

60. Marandi SM, Bagheripour MH, Rahgozar R, Zare H (2008) Strength and ductility of randomly distributed palm fibers reinforced silty-sand soils. American Journal of Applied Sciences 5: 209-220.

61. Sunny T, Joy A (2016) Study on the effects of marine clay stabilized with banana fibre. International Journal of Scientific Engineering and Research 4(3): 96-98.

62. Tran KQ, Satomi T, Takahashi H (2018) Improvement of mechanical behavior of cemented soil reinforced with waste cornsilk fibers. Construction and Building Materials 178: 204-210.

63. Villamizar MCN, Araque VS, Reyes CAR, Silva RS (2012) Effect of the addition of coal-ash and cassava peels on the engineering properties of compressed earth blocks. Construction and Building Materials 36: 276286.

64. Stulz R, Mukerji K (1981) Appropriate building materials: A catalogue of potential solutions. SKAT Publications, Switzerland.

65. Gray CA, Frost MW (2003) An investigation into Atterberg limits and their suitability for assessing the shrinkage and swelling characteristics of clay soils for foundation design, problematic soils. Nottingham, UK.

66. https://www.angelofilomeno.com/upload/BS1377-4-SoilCompaction. pdf

67.CE 240 (2010) Soil mechanics \& foundations. Lecture 3.1, Soil Consistency, Atterberg Limits (Das, Ch. 3).

68. Norton J (1986) Building with Earth: A Handbook. Intermediate Technology Publications Ltd., Great Britain, London.

69. Bui QB, Morel JC, Venkatarama Reddy BV, Ghayad W (2009) Durability of rammed earth walls exposed for 20 years to natural weathering. Building and Environment 44(5): 912-919.

70. Sharma V, Marwaha BM, Vinayak HK (2016) Enhancing durability of adobe by natural reinforcement for propagating sustainable mud housing. International Journal of Sustainable Built Environment 5(1): 141-155.

71. Aymerich F, Fenu L, Meloni P (2012) Effect of reinforcing wool fibres on fracture and energy absorption properties of an earthen material. Construction and Building Materials 27(1): 66-72.

72. Chan CM (2011) Effect of natural fibers inclusion in clay bricks: Physicomechanical properties. International Journal of Civil and Environmental Engineering 3(1): 51-57.

73. Egenti C, Khatib JM, Oloke D (2014) Conceptualisation and pilot study of shelled compressed earth block for sustainable housing in Nigeria. International Journal of Sustainable Built Environment 3(1): 72-86.

74. Jafari M, Esna Ashari M (2012) Effect of waste tire cord reinforcement on the unconfined compressive strength of lime stabilized clayey soil under freeze-thaw condition. Cold Regions Science and Technology 82: 21-29.

75. Morel J, Pkla A, Walker P (2007) Compressive strength testing of compressed earth blocks. Construction and Building Materials 21(2): 303-309.

76. Wang Q, Tang R, Cheng Q, Wang X, Liu F (2014) Research on static triaxial mechanical properties of new cement soil reinforced with polypropylene fiber. Advances in Materials Science and Engineering.

77. Yalley PP, Kwan ASK (2008) Use of waste and low energy materials in building block construction. $25^{\text {th }}$ Conference on Passive and Low Energy Architecture (PLEA), Dublin, Ireland.

78. Millogo Y, Morel JC, Aubert JE, Ghavami K (2014) Experimental analysis of pressed adobe blocks reinforced with hibiscus cannabinus fibers. Construction and Building Materials 52: 71-78. 
79. Aguwa JI (2013) Study of coir reinforced laterite blocks for buildings. Journal of Civil Engineering and Construction Technology 4(4): 110-115.

80. OtiJE, Kinuthia JM (2012) Stabilised unfired clay bricks for environmental and sustainable use. Applied Clay Science 58: 52-59.

81. http://research.iitgn.ac.in/stl/lab-manual/SPECIFIC_GRAVITY_TEST lab_manual.pdf

82. Ren XC, Lai YM, Zhang FY, Hu K (2015) Test method for determination of optimum moisture content of soil and maximum dry density. KSCE Journal of Civil Engineering 19(7): 2061-2066.

83. http://www.bits.de/NRANEU/others/amd-us-archive/fm5_410(97) pdf

84. Danso H (2016) Influence of compacting rate on the properties of compressed earth blocks. Advances in Materials Science and Engineering.
85. https://theconstructor.org/geotechnical/soil-maximum-dry-densityoptimum-moisture-content/18426/

86. Diambra A, Ibraim E, Russell AR, Muir Wood D (2013) Fibre reinforced sands: from experiments to modelling and beyond. International Journal for Numerical and Analytical Methods in Geomechanics 37: 2427-2455.

87. Nagaraj HB, Sravan MV, Arun TG, Jagadish KS (2014) Role of lime with cement in long-term strength of Compressed Stabilized Earth Blocks. International Journal of Sustainable Built Environment 3(1): 54-61.

88. MOPT (1992) Bases Para el Disen o y Construcciorn con Tapial. Centro de Publicaciones, Secretarıra General Ter'cnica, Ministerio de Obras Pur blicas y Transportes, Madrid, Spain.

89. Danso H, Martinson DB, Ali M, Williams JB (2015) Physical, mechanical and durability properties of soil building blocks reinforced with natural fibres. Construction and Building Materials 101(Part 1): 797-809.
Creative Commons Attribution 4.0 International License

For possible submissions Click Here
Submit Article

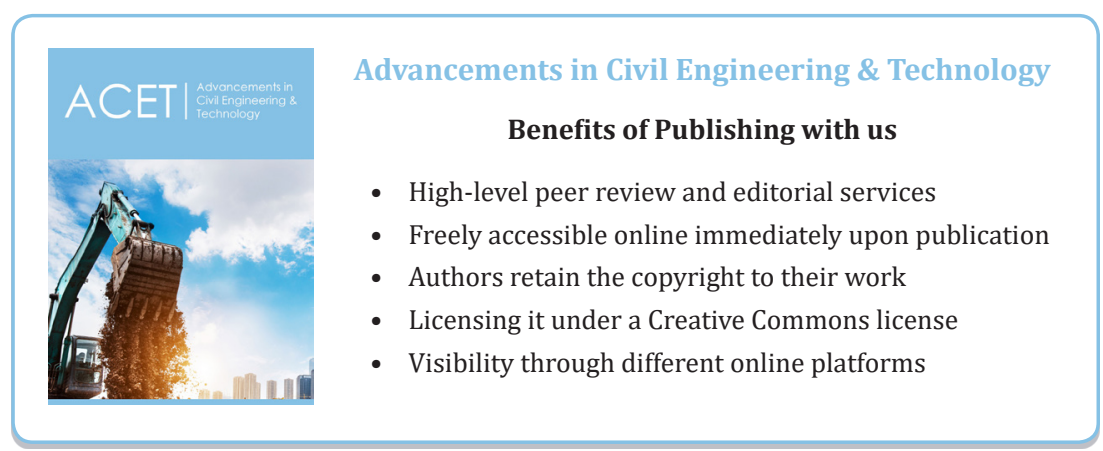

